\title{
Correction: Population movement can sustain STI prevalence in remote Australian indigenous communities
}

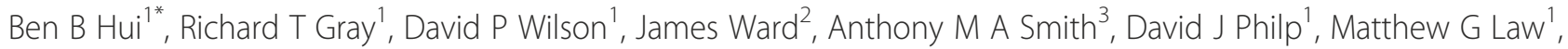
Jane S Hocking ${ }^{4}$ and David G Regan ${ }^{1}$

\section{Correction}

After the publication of this article [1] it came to our attention that there is a misspelling of one of the authors' names. The author appearing in the original article as David J Philip should be David J Philp.

\section{Author details}

'The Kirby Institute, University of New South Wales, Sydney, NSW 2052, Australia. ${ }^{2}$ Baker IDI Heart and Diabetes Institute, Alice Springs, NT 0871, Australia. ${ }^{3}$ Australian Research Centre in Sex, Health and Society, La Trobe University, Melbourne, Victoria 3000, Australia. ${ }^{4}$ Centre for Women's Health, Gender and Society, The University of Melbourne, Carlton, Victoria 3053, Australia.

Received: 13 February 2014 Accepted: 14 February 2014

Published: 19 February 2014

\section{References}

1. Hui BB, Gray RT, Wilson DP, et al: Population movement can sustain STI prevalence in remote Australian indigenous communities. BMC Infect Dis 2013, 13:188.

doi:10.1186/1471-2334-14-86

Cite this article as: Hui et al: Correction: Population movement can sustain STI prevalence in remote Australian indigenous communities. BMC Infectious Diseases 2014 14:86.

\footnotetext{
* Correspondence: bhui@kirby.unsw.edu.au

${ }^{1}$ The Kirby Institute, University of New South Wales, Sydney, NSW 2052, Australia

Full list of author information is available at the end of the article
}

Submit your next manuscript to BioMed Central and take full advantage of:

- Convenient online submission

- Thorough peer review

- No space constraints or color figure charges

- Immediate publication on acceptance

- Inclusion in PubMed, CAS, Scopus and Google Scholar

- Research which is freely available for redistribution 